УДК 666: 519.8

\title{
СТІЙКІСТЬ БЕТОНІВ ПРИ ПЕРІОДИЧНИХ ЗОВНІШНІХ ВПЛИВАХ
}

Канд. техн. наук О. О. Коробко, доктори техн. наук В. М. Вировой, В. Г. Суханов, канд. техн. наук Ю. О. Закорчемний (ОДАБА)

\section{СТОЙКОСТЬ БЕТОНОВ ПРИ ПЕРИОДИЧЕСКИХ ВНЕШНИХ ВОЗДЕЙСТВИЯХ}

Канд. техн. наук О. А. Коробко, доктора техн. наук В. Н. Выровой, В. Г. Суханов, канд. техн. наук Ю. О. Закорчемный (ОГАСА)

\section{RESISTANCE OF CONCRETES AT PERIODIC EXTERNAL INFLUENCES}

PhD (Tech.) O. Korobko, D. Sc. (Tech.) V. Vyrovoy, D. Sc. (Tech.) V. Sukhanov, PhD (Tech.) Yu. Zakorchemny

Стійкість бетонів при малоцикловій утомі визначається сітками тріщин і внутрішніх поверхонь розділу як активних елементів структури. Зміна пошкодженості матеріалу свідчить про адаптацію структури до дї зовнішніх впливів. Направлено організовувати структуру бетонів можна за рахунок збільшення структурного різноманіття шляхом зміни співвідношення адгезійно-когезійних сил зв'язку на границі розділу між иементною матрицею та поверхнею заповнювачів. 
Ключові слова: бетон, структура, тріщиини, внутрішні поверхні розділу, пошкодженість, стійкість, малочиклова утома.

Стойкость бетонов при малоцикловой усталости определяется сетями трещин и внутренними поверхностями раздела как активных элементов структуры. Изменение поврежденности материала свидетельствует об адаптащии структуры $\kappa$ внешним воздействиям. Направленно организовывать структуру бетонов можно за счет увеличения структурного разнообразия путем изменения соотношения адгезионно-когезионных сил связи на границе раздела между цементной матрицей и поверхностью заполнителей.

Ключевые слова: бетон, структура, трещины, внутренние поверхности раздела, поврежденность, стойкость, малочикловая усталость.

The purpose of the work is to increase resistance of concrete in conditions of repeated freezing-thawing and wetting-drying. An important property of concrete is its ability to adapt to the periodical effect of external factors by self-organization of the structure. It assumes the presence at the material of active elements capable of changing their parameters adequately to impacts. Such elements are cracks and inner surfaces of partition as integral elements of the structure of any material. The manifestation of adaptation effects connected with self-development of cracks can be realized as the transformation of cracks into inner surfaces of partition. It stops the growth of cracks, increases the discreteness of composites and creates preconditions for the localization of deformations and stresses in individual blocks of material. It contributes to the dissipation of excess energy on the banks of various cracks and inner surfaces of partition. The ability of cracks to redistribute deformations between blocks prevents their local accumulation that reduces the general stress-strain state of the material. Sets of active elements can be to receive by directing the structural organization of concrete. Poly-structure of concretes implies mutual influence and interaction of the structural levels at all periods of their life cycle. The operating factor of structure formation can be a change in the ratio of adhesion and cohesive bonding forces at the surface of partition between the matrix material and the fillers. In the local volumes of macrostructure of concrete, a variety of sets of active elements are formed, which at the level of the material structure integrative determine its functional potential and the conditions of interaction with the environment. Concrete whose structure was initiated by selective adhesion of a matrix to the surface of fillers differed in the raised values of properties. Sets of active elements are the factors of safe functioning of building constructions.

Keywords: concrete, structure, cracks, inner surfaces of partition, damage, resistance, low cycle fatigue.

Вступ. Останнім часом у сучасному матеріалознавстві набуває розвитку наукова концепція, яка базується на домінуючій ролі структури в реалізації поведінки матеріалу. Бетон, як матеріал будівельних виробів, при експлуатації зазнає багаторазових температурних i вологісних впливів і вимушено реагує на них спонтанною організацією структури [1, 2]. Це передбачає співіснування в матеріалі наборів структурних елементів, які практично миттєво здатні змінювати власні параметри під дією зовнішніх і внутрішніх факторів. Такими елементами $\epsilon$ технологічні та експлуатаційні тріщини і внутрішні поверхні розділу (ВПР), які присутні на всіх рівнях неоднорідностей поліструктурної будови бетонів [3, 4]. Тому аналізувати структурні зміни бетону при малоцикловій утомі доцільно через подання структури у вигляді сітки активних елементів, організованої як «сітки всередині сіток». Кожна сітка являє собою певний набір тріщин і внутрішніх 
поверхонь розділу на конкретному структурному рівні. Направлено одержувати набори активних елементів можна за рахунок регулювання організацією структури бетону на рівні макроструктури зміни співвідношення адгезійно-когезійних сил зв'язку на границі розділу між матричним матеріалом i заповнювачами. Залежно від початкового розподілу тріщин і ВПР буде визначатися зміна пошкодженості бетону як прояв ефектів адаптації, що забезпечують підтримку заданого рівня механічних і деформативних властивостей матеріалу в складних умовах експлуатації.

Аналіз останніх досліджень і публікацій. Будівельні композити, включаючи бетони, можна представити як системні цілісності, що являють собою ієрархію взаємозалежних різномасштабних структур (підсистем) [3, 5]. Всі підструктури здатні вступати у взаємодії, реагувати на вплив зовнішніх факторів і викликати взаємні структурні зміни, ініціюючи прояв деформацій $[1,6,7]$. Крім того, широкий спектр окремих взаємозв'язаних підструктур дає проявитися багатоманітним ефектам адаптації при дії навколишнього середовища. Тому аналізувати умови структурної самоорганізації та формування властивостей будівельних композитів доцільно в рамках структурного підходу на основі їх моделі як багатофункціональних систем [5, 8]. При цьому необхідно враховувати структурну нероздільність і взаємозв'язаний прояв властивостей будівельного виробу і матеріалу, з якого він виготовлений, i функції тріщин у структуроутворенні та руйнуванні конструкцій як складно організованих систем [9]. На підставі цього можна оцінити вплив окремих підструктур на умови безпеки функціонування виробу.

Визначення мети та завдань дослідження. Подання будівельних виробів як системи, що самоорганізується та $\epsilon$ відкритою до зовнішніх факторів $[1,2]$, дає змогу виявити фактори взаємообумовле- ного формування різнорівневих підструктур бетону для одержання заданого набору структурних елементів, які визначають збереження проектного рівня властивостей виробу в різних умовах експлуатації. Отже, мета дослідження підвищення стійкості бетонів на щільних і пористих заповнювачах при малоцикловій утомі, пов'язаній з періодичними циклами зволоження-висушування і заморожуваннявідтавання, завдяки забезпеченню структурного різноманіття на макрорівні.

Для досягнення сформульованої мети потрібно вирішити такі завдання:

- проаналізувати прояв реакцій матеріалу як сітки тріщин i внутрішніх поверхонь розділу на дію навколишнього середовища;

- визначити коефіцієнти стійкості бетону та керамзитобетону при періодичних зовнішніх впливах.

Основна частина досліджень. Досліди проводили на зразках-кубах розміром $100 \times 100 \times 100 \mathrm{MM}$, які були виготовлені з бетону та керамзитобетону. Наряду 3 традиційними складами використовували бетони на заповнювачах 3 різним станом поверхні. Частину щебеня чи гравію (у кількості 50 \% за масою загальної кількості заповнювачів у бетонній суміші) піддавали гідрофобізації речовиною ГКР-11 марки А вітчизняного виробництва шляхом повного занурення зерен на 5-10 хвилин у розчин гідрофобізатора концентрацією $2 \%$ за масою 3 подальшим ї висушуванням при $\mathrm{T} \leq 100^{\circ} \mathrm{C}$. Це забезпечило різноманітні співвідношення адгезійно-когезійних сил зв'язку на границі розділу між цементною матрицею і заповнювачами в бетоні одного складу: $\mathrm{R}_{\mathrm{A}}>\mathrm{R}_{\mathrm{K}}, \mathrm{R}_{\mathrm{A}}<\mathrm{R}_{\mathrm{K}}, \mathrm{R}_{\mathrm{A}}=\mathrm{R}_{\mathrm{K}}$, де $\mathrm{R}_{\mathrm{A}}-$ величина адгезії матриці до поверхні заповнювачів, $\mathrm{R}_{\mathrm{K}}$ - величина когезійної міцності матричного матеріалу.

Залежно від умов взаємодії цементної матриці 3 заповнювачами було виконано коректування складів бетону за значеннями В/Ц. При постійній рухливості бетонної суміші одержано звичайний бетон класів: 
$\mathrm{C} 30 / 35$ при $\mathrm{R}_{\mathrm{A}}>\mathrm{R}_{\mathrm{K}}, \mathrm{C} 25 / 30$ при $\mathrm{R}_{\mathrm{A}}<\mathrm{R}_{\mathrm{K}}$, $\mathrm{C} 32 / 40$ при $\mathrm{R}_{\mathrm{A}}=\mathrm{R}_{\mathrm{K}}$ та керамзитобетон класу LC 12/13 при $\mathrm{R}_{\mathrm{A}}>\mathrm{R}_{\mathrm{K}}$ i класу LC 16/18 при $\mathrm{R}_{\mathrm{A}}<\mathrm{R}_{\mathrm{K}}$ та $\quad \mathrm{R}_{\mathrm{A}}=\mathrm{R}_{\mathrm{K}} \quad 3 \quad$ відповідними показниками властивостей.

Пошкодженість матричного матеріалу оцінювали через коефіцієнт пошкодженості Кп:

- як відношення Кп $=\sum \mathrm{L}_{\mathrm{i}} / \mathrm{S}, \mathrm{cm} / \mathrm{cm}^{2}$, де $\quad \sum \mathrm{L}_{\mathrm{i}} \quad$ с сумарна протяжність технологічних тріщин і внутрішніх поверхонь розділу на виділеній поверхні зразка, см; S - фіксована площа поверхні зразка, $\mathrm{cm}^{2}$;

- як відношення $\mathrm{K}_{\Pi_{1}}=\sum \mathrm{L}_{\mathrm{i}} / \mathrm{L}_{\mathrm{i}}$, де $\sum \mathrm{L}_{\mathrm{i}}-$ сумарна протяжність берегів окремих тріщин i внутрішніх поверхонь розділу (фактична довжина тріщини руйнування), см, вздовж геодезичної лінії $\mathrm{L}_{\mathrm{i}}, \mathrm{cm}$ (найкоротша відстань між точками виходу фактичної тріщини руйнування на торцеві поверхні зразка).

Виміри проводили по 5 сторонах, крім верхньої, кожного зразка, вираховуючи Кп як середне арифметичне одержаних значень.

Сумарна кількість тріщин і ВПР визначає гетерогенність матеріалу та його пошкодженість початковими активними елементами. У роботі [3] пропонується розглядати «пошкодженість» як характеристику структури, що відображує розподіл тріщин i внутрішніх поверхонь розділу в об'ємі матеріалу.

Показники міцності при стиску (f $\left.\mathrm{f}_{\text {ck.cube, }} \mathrm{MПа}\right)$, модуля пружності (E, $\left.\mathrm{MПа} \cdot 10^{3}\right)$, відкритої пористості $\left(\Pi_{0}, \%\right)$, середньої густини $\left(\rho_{\omega}, \quad \kappa \Gamma / \mathrm{M}^{3}\right)$, водопоглинання (W, \%) i маси $(\mathrm{m}$, г) бетонних зразків до та після кожного циклу періодичних температурних i вологісних впливів визначали за стандартними методиками. На основі одержаних значень різних властивостей були вирахувані коефіцієнти стійкості бетону i керамзитобетону при поперемінному заморожуванні-відтаванні та зволоженнівисушуванні. Коефіцієнти стійкості визначали як відношення $\mathrm{K}_{\text {ст }}=\mathrm{Q}^{\mathrm{N}} / \mathrm{Q}^{28}$, де $\mathrm{Q}^{\mathrm{N} \text { L }}$ - показник властивості бетонів після певної кількості циклів впливу, $\mathrm{Q}^{28}-$ показник властивості бетонів після 28 діб нормального тверднення.

Під структурним різноманіттям слід розуміти співіснування взаємозалежнопідпорядкованих підструктур бетону, організованих за якісно відмінними механізмами структуроутворення [3, 4]. Різномасштабність підструктур, які складаються 3 наборів характерних лише для них структурних елементів, передбачає їхню здатність до взаємовпливу при формуванні інтегральної структури матеріалу та виконанні виробом закладених у нього функцій. Тому структурне різноманіття є важливим фактором безпеки функціонування будівельного виробу i стійкості матеріалу, який визначається переважно проявом взаємодій різноманітних підструктур і їхніми взаємозв'язками. Це сприяє переорганізації структури бетону в одному темпоритмі зі зміною зовнішніх умов [3].

Аналіз експериментальних результатів показав, що поліпшеними показниками відрізнялися бетони, структура яких буда ініційована вибірковою адгезією матриці до поверхні заповнювачів $\left(\mathrm{R}_{\mathrm{A}}=\mathrm{R}_{\mathrm{K}}\right)$. Зміна співвідношень сил зв'язку на границях розділу між матричним матеріалом i заповнювачами позначається на параметрах структури бетону та керамзитобетону, що було підтверджено зміною показників середньої густини, пористості та початкової пошкодженості композиційних матеріалів. Значення Кп бетонів прийнятих складів відрізнялися в середньому на $25 \%$. При вибірковій адгезії матеріалу до заповнювачів пошкодженість цементної матриці зросла до $29 \%$ в бетонах на гранітовому щебені та зменшилась до 39 \% в бетонах на керамзитовому гравії порівняно з бетонами традиційних складів. При організації структури в умовах $R_{A}=R_{K}$ важкий бетон i керамзитобетон відзначалися меншою величиною 
капілярної пористості та підвищеними показниками міцності і модуля пружності в середньому на $20 \%$ і $15 \%$ відповідно при зменшенні показників водопоглинання до 14-24 \% і глибини карбонізації до 6 мм.

$$
\text { Деформації різних видів }
$$
проявляються на всіх етапах «життєвого» циклу структури матеріалу будівельних виробів. Це дозволяє віднести деформації до ключових факторів з визначення умов взаємообумовленої реалізації процесів структуроутворення складної ієрархії рівнів неоднорідностей і формування властивостей виробу-системи. Деформації слід розглядати 3 урахуванням їхньої безперервної участі в становленні та самозбереженні структури матеріалу. Спроможність неоднорідностей бетону та їхніх складових передавати, сприймати, перерозподіляти і релаксувати локальні та інтегральні деформації різного виду

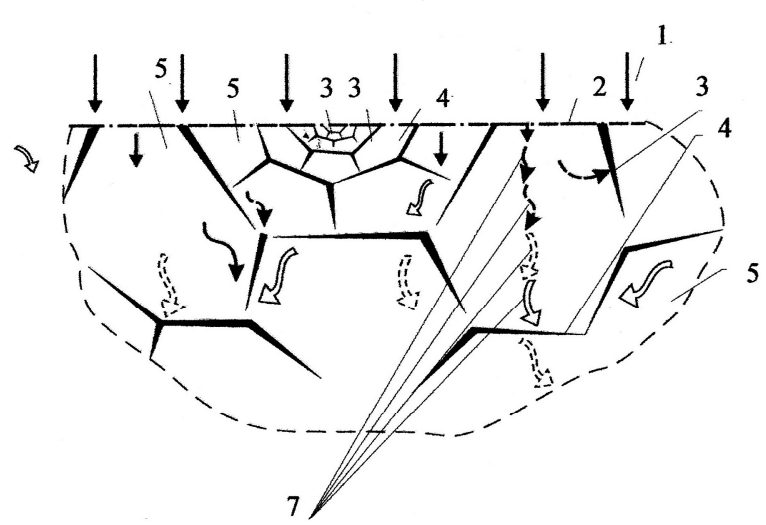

a) визначає їхній структурний розвиток 3 виходом на оформлення структури інших рівнів. Деформації залежно від причин їх виникнення пропонується поділяти на ендо- та екзодеформації. Це обгрунтовано тим, що внутрішні та зовнішні впливи, на які реагує бетон при експлуатації виробу, відбуваються одночасно. Зумовлюється синхронний прояв деформацій у двох напрямках (рис. 1): «знизу - вверх» 3 рівня мікроструктури через макрорівень на рівень виробу та «зверху - вниз» 3 рівня виробу через макрорівень на рівень мікроструктури. Таким чином, розвиток деформацій має відбуватися у вигляді хвиль, які зворотно передаються між рівнями та підструктурами самих рівнів. Деформації можна представити як фактори ініціювання структурних змін на кожному рівні та водночас як конкретний результат прояву цих змін.

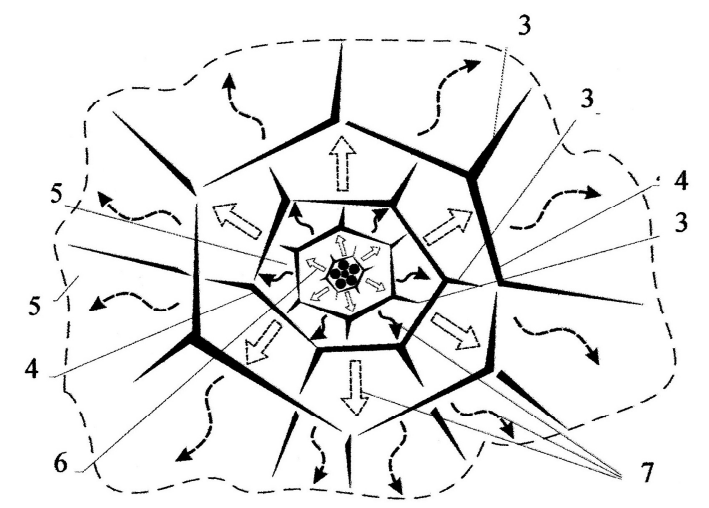

б)

Рис. 1. Реакції різнорівневої структури матеріалу виробу на вплив зовнішніх (а) і внутрішніх факторів (б):

1 - зовнішні впливи; 2 - умовна границя поверхні матеріалу (виробу); 3 - технологічні тріщини; 4 - внутрішні поверхні розділу; 5 - структурні блоки; 6 - внутрішні впливи; 7 - реакції активних елементів на різних рівнях структурних неоднорідностей на зовнішні та внутрішні впливи

Зовнішні впливи сприймаються всіма рівнями неоднорідностей, що викликає переорганізацію їхньої структури. При цьому енергія деформування може частково розсіюватися на внутрішніх поверхнях розділу та берегах тріщин або може спричинювати підростання тріщин чи перерозподілятися всередині рівнів і між ними. Структурні зміни, що реалізувалися, проявляють себе як вибіркові реакції 
різнорівневої структури бетону на зовнішні впливи у вигляді градієнтів деформацій. Деформаційна хвиля сприймається іншим рівнем неоднорідностей і переходить по відношенню до нього в ранг внутрішніх факторів впливу. Це провокує подальші структурні зміни всіх взаємодіючих рівнів 3 підвищенням різноманіття параметрів їхніх складових. Разом 3 тим на рівні мікроструктури продовжуються процеси гідратації реліктових зерен в'яжучого 3 локалізацією об’ємних i температурних деформацій у кластерних структурах. Формозміна границь розділу, ініційована градієнтами деформацій, забезпечує протилежний напрямок передачі деформаційних хвиль, що сприяє збільшенню структурного різноманіття бетону на всіх рівнях неоднорідностей.

Складна організація багаторівневої структури бетону дозволяе припустити співіснування тріщин і ВПР в матеріалі виробів у вигляді сітки-павутини. Така сітка утворюється за принципом «сітки всередині сіток» (рис. 2). Інтегральна сітка включає індивідуальні локальні сітки, які складаються з власних сіток. Активна роль тріщин $\mathrm{i}$ ВПР в процесах структуроутворення та функціонування матеріалів дозволяє подати структуру бетону та структуру виробу у вигляді сітки тріщин і внутрішніх поверхонь розділу. Характеристики цих своєрідних сіток визначають неповторність структурного оформлення виробу на окремих рівнях неоднорідностей після закінчення технологічного етапу його життєвого циклу. Від геометричних параметрів різнорівневої сітки тріщин і ВПР залежить прояв потенційних можливостей виробу в період експлуатації.

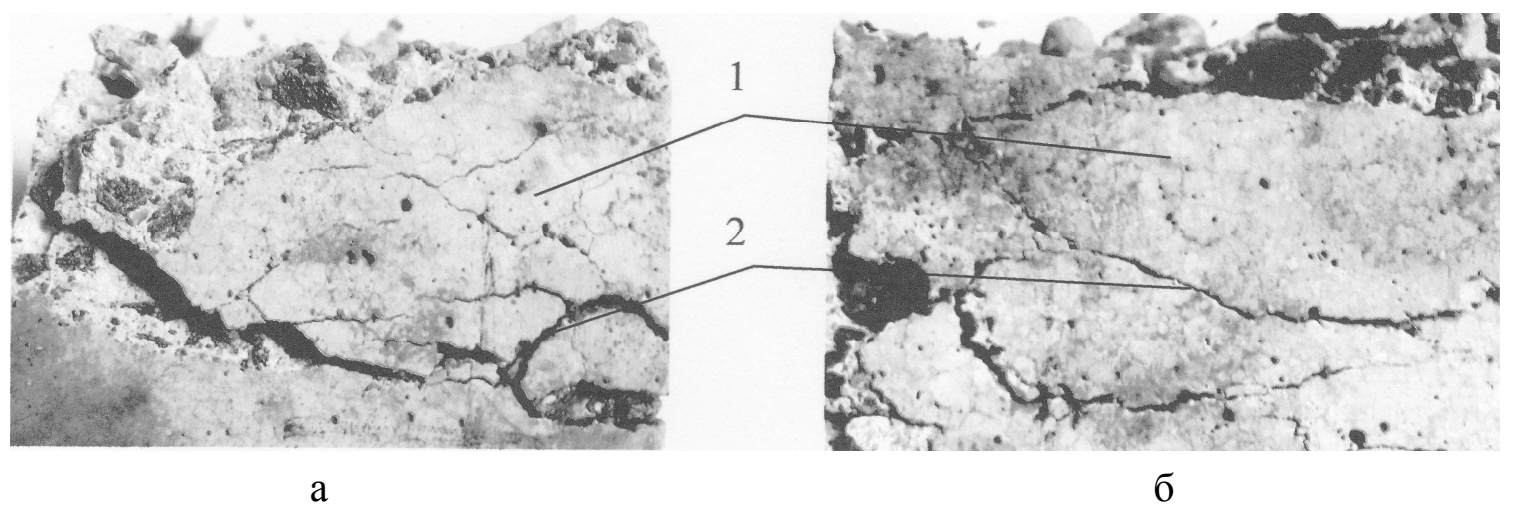

Рис. 2. Сітка тріщин і внутрішніх поверхонь розділу як активних елементів структури важкого бетону (а) і керамзитобетону (б):

1 - сітка тріщин і ВПР, що присутні в матеріалі до експлуатації виробу;

2 - магістральні тріщини (тріщини руйнування)

Будь-які впливи експлуатаційного середовища, що діють на будівельний виріб, сприймаються сіткою тріщин і внутрішніх границь розділу. Тріщини і ВПР здатні через зміну власних параметрів забезпечити необхідний інтервал часу для відновлювальних структурних перебудов. Відбувається самопідтримка матеріалом своєї цілісності, що дозволяє зберігати властивості виробу на допустимому нормами рівні. Матеріал виробу адаптується до різного роду впливів шляхом зміни параметрів сіток тріщин $\mathrm{i}$ ВПР із включенням у роботу консервативних i метастабільних структурних складових [3]. Взаємовплив i взаємодія сіток активних елементів реалізується через внутрішньоструктурні та 
міжструктурні зв'язки. Адекватний прояв структурних змін на зовнішні та внутрішні впливи забезпечує самозбереження кожного рівня структури бетону внаслідок локалізації зростання тріщин всередині окремих неоднорідностей, що запобігає їх злиттю в тріщину руйнування. Розрив міжструктурних зв'язків провокує зародження та розвиток магістральної тріщини, що поступово викликає втрату функцій матеріалу. Сприятливі зміни структури запобігають локальному накопиченню деформацій у матеріалі. Динамічність зв'язків сіток тріщин і ВПР на окремих рівнях неоднорідностей робить можливим релаксацію деформацій i стабілізацію загального стану бетону на рівні виробу. Для підвищення стійкості бетону необхідно створювати набори сіток тріщин і ВПР, які будуть гарантувати своєчасність прояву структурних змін при періодичних зовнішніх впливах.

Розвиток тріщин у матеріалах 3 блоковою структурою можна представити як дискретно-безперервний процес. Це пов'язано 3 покроковим підростанням тріщин після закінчення дії впливу. Поведінкові реакції бетону на дію вологих і температурних факторів проявляються у вигляді перебудови сіток тріщин і ВПР та повторюються від циклу до циклу. Проте результат змін, що відбулися в структурі матеріалу, залежить від попередньої трансформації сіток, прояв якої спадково зумовлюється їхнім початковим оформленням. Прояв ефектів адаптації, пов'язаних із саморозвитком тріщин, може реалізовуватися як трансформація тріщин у внутрішні поверхні розділу, які не мають головного атрибуту тріщини - устя (концентратора напружень i деформацій) [1]. Припиняється підростання тріщин і збільшується дискретність будови, що створює умови для локалізації деформацій і напружень в окремих блоках матеріалу. Це сприяє дисипації залишкової енергії на берегах тріщин i внутрішніх поверхнях розділу. Здатність тріщин і ВПР перерозподіляти градієнти деформацій між окремими блоками перешкоджає їхньому локальному накопиченню, що веде до зниження інтегрального напруженодеформативного стану композитів.

Експериментальні дослідження підтвердили можливість підвищення стійкості бетонів на щільних і пористих заповнювачах за рахунок направленої організації їхньої структури шляхом забезпечення різноманіття умов взаємодії матричної складової 3 поверхнею заповнювачів на границі розділу між ними.

Були визначені коефіцієнти стійкості бетону та керамзитобетону за зміною показників втрати маси, відкритої пористості, водопоглинання, міцності при стиску та модуля пружності (таблиця).

Проведені дослідження показали, що пошкодженість бетонів збільшилась у середньому на $40 \%$ (важкий бетон) і $30 \%$ (керамзитобетон) після 100 циклів поперемінних зовнішніх впливів.

Показник коефіцієнта пошкодженості Кп1 був меншим при збільшенні показника коефіцієнта пошкодженості Кп. Порівняно 3 величиною пошкодженості бетонів традиційних складів бетони 3 вибірковою адгезією цементної матриці до поверхні заповнювачів мали структуру, при якій значення Кп є більшими на 11-15\%, значення Кп $\Pi_{1}$ меншими на 20-25\%. Це свідчить про те, що збільшення структурного різноманіття веде до формування структури, при якій початковий розподіл тріщин запобігає їх зростанню до розмірів, що $\epsilon$ небезпечними для певного рівня неоднорідностей та всього матеріалу.

Бетони, організація структури яких була ініційована при початковій умові $\mathrm{R}_{\mathrm{A}}=\mathrm{R}_{\mathrm{K}}$, мали поліпшені значення властивостей. Показники міцності при стиску практично не змінювалися після циклів періодичних впливів, модуль пружності підвищився на $11 \%$, відкрита пористість знизилась на 7-10\%, водопоглинання змінилося не більше $5 \%$ 
(бетон) i $15 \%$ (керамзитобетон), втрата маси склала до $2 \%$. Для бетонів при інших прийнятих співвідношеннях $\quad \mathrm{R}_{\mathrm{A}} / \mathrm{R}_{\mathrm{K}}$ показники міцності та модуля пружності зменшились до $5 \%$ та $18 \%$ відповідно при збільшенні водопоглинання на 3-13\% і відкритій пористості на 11-14\%, втрата маси досягала $5 \%$. Збільшення пошкодженості свідчить про структурні зміни, завдяки яким властивості бетону підтримуються на рівні не нижче проектного.

Таблиця

Стійкість бетону та керамзитобетону при малоцикловій утомі

\begin{tabular}{|c|c|c|c|c|c|c|c|c|c|c|c|c|c|c|c|}
\hline \multirow{2}{*}{$\begin{array}{l}\text { Номер } \\
\text { циклу }\end{array}$} & \multicolumn{3}{|c|}{$\mathrm{K}_{\mathrm{cT}}=\mathrm{f}_{\mathrm{ck}}{ }^{N \amalg / f_{\mathrm{ck}}}{ }^{28}$} & \multicolumn{3}{|c|}{$\mathrm{K}_{\mathrm{cT}}=\mathrm{E}^{\mathrm{N}_{\mathrm{L}}} / \mathrm{E}^{28}$} & \multicolumn{3}{|c|}{$\mathrm{K}_{\mathrm{cT}}=\mathrm{W}^{\mathrm{N}} / \mathrm{W}^{28}$} & \multicolumn{3}{|c|}{$\mathrm{K}_{\mathrm{cT}}=\prod_{\mathrm{o}}^{\mathrm{N}} / \Pi_{\mathrm{o}}^{28}$} & \multicolumn{3}{|c|}{$\mathrm{K}_{\mathrm{cT}}=\mathrm{m}^{\mathrm{N}} / \mathrm{m}^{28}$} \\
\hline & $\mathrm{I}$ & II & III & $\mathrm{I}$ & II & III & $\mathrm{I}$ & II & III & $\mathrm{I}$ & II & III & $\mathrm{I}$ & II & III \\
\hline \multicolumn{16}{|c|}{ Бетон } \\
\hline $\mathrm{T}=0$ & 1 & 1 & 1 & 1 & 1 & 1 & 1 & 1 & 1 & 1 & 1 & 1 & 1 & 1 & 1 \\
\hline $\mathrm{T}=50$ & 0,97 & 0,98 & 0,99 & 1,04 & 0,96 & 1,24 & 0,85 & 0,93 & 0,76 & 0,84 & 0,90 & 0,77 & 0,99 & 0,98 & 0,99 \\
\hline $\mathrm{T}=100$ & 0,96 & 0,96 & 0,98 & 1,02 & 0,94 & 1,12 & 0,97 & 0,99 & 0,95 & 0,92 & 0,94 & 0,93 & 0,95 & 0,95 & 0,97 \\
\hline $\mathrm{W}=0$ & 1 & 1 & 1 & 1 & 1 & 1 & 1 & 1 & 1 & 1 & 1 & 1 & 1 & 1 & 1 \\
\hline $\mathrm{W}=50$ & 1,02 & 1 & 1 & 1,28 & 1,11 & 1,32 & 0,90 & 0,97 & 0,88 & 0,88 & 0,93 & 0,88 & 0,98 & 0,98 & 0,99 \\
\hline $\mathrm{W}=100$ & 1 & 0,98 & 0,99 & 1,22 & 1,02 & 1,29 & 1,04 & 1,03 & 1,0 & 0,99 & 0,98 & 1,0 & 0,95 & 0,95 & 0,98 \\
\hline \multicolumn{16}{|c|}{ Керамзитобетон } \\
\hline $\mathrm{T}=0$ & 1 & 1 & 1 & 1 & 1 & 1 & 1 & 1 & 1 & 1 & 1 & 1 & 1 & 1 & 1 \\
\hline $\mathrm{T}=50$ & 0,97 & 0,98 & 1 & 0,86 & 0,95 & 0,93 & 0,78 & 0,82 & 0,73 & 0,76 & 0,81 & 0,71 & 0,98 & 0,98 & 1 \\
\hline $\mathrm{T}=100$ & 0,95 & 0,95 & 0,98 & 0,82 & 0,9 & 0,89 & 0,89 & 0,92 & 0,83 & 0,85 & 0,87 & 0,81 & 0,95 & 0,95 & 0,97 \\
\hline $\mathrm{W}=0$ & 1 & 1 & 1 & 1 & 1 & 1 & 1 & 1 & 1 & 1 & 1 & 1 & 1 & 1 & 1 \\
\hline $\mathrm{W}=50$ & 1 & 1,01 & 1,03 & 1,11 & 1,17 & 1,03 & 0,92 & 1,01 & 0,96 & 0,91 & 0,96 & 0,98 & 0,99 & 0,97 & 0,99 \\
\hline $\mathrm{W}=100$ & 0,97 & 0,99 & 0,99 & 1,07 & 1,12 & 0,99 & 1,12 & 1,15 & 1,16 & 1,06 & 1,08 & 1,16 & 0,96 & 0,95 & 0,96 \\
\hline
\end{tabular}

Таким чином, забезпечення багатоваріантності умов структуроутворення в початковий період дозволило одержати структури бетону та керамзитобетону 3 заданими наборами активних елементів. Регулювання різноманіттям структури на макрорівні дає змогу підвищити стійкість будівельних виробів i конструкцій, призначених для використання в умовах періодичних змін вологи і температури в зовнішньому середовищі.

Висновки. Аналіз результатів експериментальних досліджень і їхнє теоретичне обгрунтування дозволили заключити, що збереження початкового рівня фізикотехнічних властивостей бетонів при малоцикловій утомі, викликаній циклами заморожування-відтавання i зволоженнявисушування, залежить від початкової організації та своєчасної переорганізації структури. Прояв ефектів адаптації пов'язаний переважно зі спонтанним розвитком тріщин і внутрішніх поверхонь розділу як активних елементів структури. Зміна параметрів тріщин і ВПР, що проявляється як зміна локальної та інтегральної пошкодженості матеріалу, являє собою реакції структури на вплив зовнішніх i внутрішніх факторів. Для забезпечення структур із заданими наборами активних елементів раціональним підходом $\epsilon$ регулювання структурним різноманіттям на рівні макроструктури бетону. Направлена зміна співвідношення адгезійно-когезійних сил зв'язку на границі розділу між матричною складовою $\mathrm{i}$ поверхнею заповнювачів зумовлює одержання бетонів, які відзначаються підвищеною стійкістю при поперемінних температурних і вологісних впливах. 
Наведені результати і висновки вказують на перспективність досліджень 3 виявлення факторів направленого формування складно організованої структури будівель- них композитів 3 метою підвищення показників їхньої якості для використання в складних умовах експлуатації.

\section{Список використаних джерел}

1. Суханов, В. Г. Структура материала в структуре конструкции [Текст] / В. Г. Суханов, В. Н. Выровой, О. А. Коробко. - Одесса : Полиграф, 2016. - 244 с.

2. Чернявский, В. Л. Адаптация абиотических систем: бетон и железобетон [Текст] / В. Л. Чернявский. - Днепропетровск : ДНУЖТ, 2008. - 412 с.

3. Выровой, В. Н. Композиционные строительные материалы и конструкции. Структура, самоорганизация, свойства [Текст] / В. Н. Выровой, В. С. Дорофеев, В. Г. Суханов. - Одесса : ТЭС, 2010. - 169 с.

4. Полиструктурная теория композиционных строительных материалов [Текст] / В. И. Соломатов, В. Н. Выровой, А. Н. Бобрышев [и др.]. - Ташкент : ФАН, 1991. - 345 с.

5. Системный поход к разработке и управлению качеством строительных материалов [Текст] / Ю. М. Баженов, А. М. Данилов, И. А. Гарькина [и др.]. - М. : ПАЛЕОТИП, 2006. $188 \mathrm{c}$.

6. Выровой, В.Н. Системный подход при анализе структуры строительных конструкций [Текст] / В. Н. Выровой, А. В. Дорофеев, В. Г. Суханов // Ресурсоекономні матеріали, конструкції, будівлі та споруди. - 2008. - Вип. 41. - Ч. 1. - С. 133-139.

7. Formation of structure of high-strength composites with account of interactions between liquid phase and disperse particles [Text] / A. Plugin, E. Dedeneva, T. Kostyuk, D. Bondarenko, O. Demina // Open Access Journal «MATEC Web of Conferences». - V. 116. - DOI: 0.1051/matecconf/ 201711601010. - EDP Sciences. - 2017.

8. Гарькина, И. А. Строительные материалы как системы [Текст] / И. А. Гарькина, А. М. Данилов, Е. В. Королев // Строительные материалы. - 2006. - № 7. - С. 55-58.

9. Функции трещин в конструкциях как сложноорганизованных системах [Текст] // А. Н. Герега, В. Н. Выровой, В. С. Дорофеев, В. Г. Суханов // Материалы междунар. конф. «Механика разрушения бетона, железобетона и других строительных материалов». - 2012. C. 14-17.

Коробко Оксана Олександрівна, канд. техн. наук, доцент кафедри архітектурних конструкцій Одеської державної академії будівництва та архітектури. Тел: (096)36-90-522. E-mail: okskorobko71@gmail.com. Вировой Валерій Миколайович, д-р техн. наук, професор кафедри виробництва будівельних виробів та конструкцій Одеської державної академії будівництва та архітектури. Тел: (097)48-94-979. E-mail: vyrovoy@ukr.net. Суханов Володимир Геннадійович, д-р техн. наук, професор кафедри виробництва будівельних виробів та конструкцій Одеської державної академії будівництва та архітектури. Тел: (067)48-04-113. E-mail: suxan-ov@mail.ua. Закорчемний Юрій Орестович, канд. техн. наук, доцент кафедри архітектурних конструкцій Одеської державної академії будівництва та архітектури. Тел: (098)55-24-607. E-mail: zakorchemny@gmail.com.

Коробко Оксана Александровна, канд. техн. наук, доцент кафедры архитектурных конструкций Одесской государственной академии строительства и архитектуры. Тел: (096)36-90-522. E-mail: okskorobko71@gmail.com. Выровой Валерий Николаевич, д-р техн. наук, профессор кафедры производства строительных изделий и конструкций Одесской государственной академии строительства и архитектуры. Тел: (097)48-94-979.

E-mail: vyrovoy@ukr.net.

Суханов Владимир Геннадиевич, д-р техн. наук, профессор кафедры производства строительных изделий и конструкций Одесской государственной академии строительства и архитектуры. Тел: (067)48-04-113.

E-mail: suxanov@mail.ua. 
Закорчемный Юрий Орестович, канд. техн. наук, доцент кафедры архитектурных конструкций Одесской государственной академии строительства и архитектуры. Тел: (098)55-24-607. E-mail: zakorchemny@gmail.com.

Korobko Oksana, $\mathrm{PhD}$ (Tech.), associate professor, Department of Architectural Constructions Odessa State Academy Civil Engineering and Architecture. Tel.: (096)36-90-522. E-mail: okskorobko71@gmail.com.

Vyrovoy Valery, D. Sc. (Tech.), professor, Department of Production of Building Products and Constructions Odessa State Academy Civil Engineering and Architecture. Tel: (097)48-94-979. E-mail: vyrovoy@ukr.net.

Sukhanov Vladimir, D. Sc. (Tech.), professor, Department of Production of Building Products and Constructions Odessa State Academy Civil Engineering and Architecture. Tel: (067)48-04-113. E-mail: suxanov@mail.ua. Zakorchemny Yuri, PhD (Tech.), associate professor, Department of Architectural Constructions Odessa State Academy Civil Engineering and Architecture. Tel: (098)55-24-607. E-mail: zakorchemny@gmail.com.

Статтю прийнято 01.11.2018 p. 